\title{
Knowledge Spillovers and Entrepreneurs' Export Orientation
}

\author{
Dirk De Clercq, Jolanda Hessels and André van Stel
}

\begin{tabular}{|l|l|}
\hline \multicolumn{2}{|l|}{ ERIM REPORT SERIES RESEARCH IN MANAGEMENT } \\
\hline ERIM Report Series reference number & ERS-2007-038-ORG \\
\hline Publication & June 2007 \\
\hline Number of pages & 27 \\
\hline Persistent paper URL & \\
\hline Email address corresponding author & joh@eim.nl \\
\hline Address & Erasmus Research Institute of Management (ERIM) \\
& RSM Erasmus University / Erasmus School of Economics \\
& Erasmus Universiteit Rotterdam \\
& P.O.Box 1738 \\
& 3000 DR Rotterdam, The Netherlands \\
& Phone: + 31104081182 \\
& Fax: $\quad+31104089640$ \\
& Email: info@erim.eur.nl \\
& Internet: $\quad$ www.erim.eur.nl \\
\hline
\end{tabular}

Bibliographic data and classifications of all the ERIM reports are also available on the ERIM website: www.erim.eur.nl 


\section{ERASMUS RESEARCH INSTITUTE OF MANAGEMENT}

\section{REPORT SERIES}

\section{RESEARCH IN MANAGEMENT}

\begin{tabular}{|l|l|}
\hline \multicolumn{2}{|l|}{ ABSTRACT AND KEYWORDS } \\
\hline Abstract & $\begin{array}{l}\text { We draw on knowledge spillover literature to suggest that a country's level of foreign direct } \\
\text { investment (FDI) and international trade may influence the export orientation of its } \\
\text { entrepreneurs, which in turn may relate to the country's total level of entrepreneurial activity. } \\
\text { Macro-level data from 34 countries during 2002-2005 indicate that a country's outward FDI, } \\
\text { export, and import positively affect entrepreneurs' export orientation, but these effects differ in } \\
\text { how fast they manifest themselves. Furthermore, the extent to which a country's entrepreneurs } \\
\text { engage in export-oriented activities affects the subsequent emergence of new businesses. } \\
\text { These findings have important implications for research and practice. }\end{array}$ \\
\hline Free Keywords & Knowledge spillovers, Export orientation, Country-level entrepreneurship \\
\hline Availability & $\begin{array}{l}\text { The ERIM Report Series is distributed through the following platforms: } \\
\text { Academic Repository at Erasmus University (DEAR), DEAR ERIM Series Portal } \\
\text { Social Science Research Network (SSRN), SSRN ERIM Series Webpage } \\
\text { Research Papers in Economics (REPEC), REPEC ERIM Series Webpage }\end{array}$ \\
\hline Classifications & $\begin{array}{l}\text { The electronic versions of the papers in the ERIM report Series contain bibliographic metadata } \\
\text { by the following classification systems: } \\
\text { Library of Congress Classification, (LCC) } \underline{\text { LCC Webpage }} \\
\text { Journal of Economic Literature, (JEL), JEL Webpage } \\
\text { ACM Computing Classification System CCS Webpage } \\
\text { Inspec Classification scheme (ICS), ICS Webpage }\end{array}$ \\
\hline
\end{tabular}




\title{
Knowledge Spillovers and Entrepreneurs' Export Orientation
}

\author{
Dirk De Clercq ${ }^{\mathrm{A}}$ \\ Jolanda Hessels ${ }^{\text {B }}$ \\ André van Stel ${ }^{\text {B, C, D }}$
}

${ }^{\text {A }}$ Brock University, St. Catharines, Ontario, Canada

${ }^{B}$ EIM Business and Policy Research, Zoetermeer, The Netherlands

${ }^{\text {C }}$ Cranfield School of Management, Cranfield University, UK

${ }^{D}$ Erasmus University Rotterdam, The Netherlands

\begin{abstract}
:
We draw on knowledge spillover literature to suggest that a country's level of foreign direct investment (FDI) and international trade may influence the export orientation of its entrepreneurs, which in turn may relate to the country's total level of entrepreneurial activity. Macro-level data from 34 countries during 2002-2005 indicate that a country's outward FDI, export, and import positively affect entrepreneurs' export orientation, but these effects differ in how fast they manifest themselves. Furthermore, the extent to which a country's entrepreneurs engage in export-oriented activities affects the subsequent emergence of new businesses. These findings have important implications for research and practice.
\end{abstract}

Version: June 2007

Keywords: knowledge spillovers, export orientation, country-level entrepreneurship

JEL-classification: F14, F21, F23, L26, O57

Correspondence: Jolanda Hessels, joh@eim.nl

Acknowledgement: The paper has been written in the framework of the research programme SCALES (SCientific AnaLysis of Entrepreneurship and SMEs), carried out by EIM and financed by the Dutch Ministry of Economic Affairs. 


\section{INTRODUCTION}

Increasing evidence indicates firms engage in international activities early in their existence; some ventures are even born global and reap the benefits of an immediate presence in the international marketplace (Knight \& Cavusgil, 1996; McDougall \& Oviatt, 2000). Entrepreneurship literature examining the early entry of new firms into foreign markets relates internationalization mainly to individual-level factors, such as entrepreneurs' international experience (Bloodgood, Sapienza \& Almeida, 1996; McDougall, Shane, \& Oviatt, 1994; Oviatt \& McDougall, 1995), or firm-level factors, such as entrepreneurial orientation (Sapienza, De Clercq, \& Sandberg, 2005) or a technology or knowledge base (Autio, Sapienza \& Almeida, 2000; Keeble, Lawson, Smith, Moore, \& Wilkinson, 1998). Although it sporadically notes the importance of macro-level environmental conditions (e.g., economic integration, transportation advances) to explain the emergence of international start-ups (Bloodgood et al., 1996; Knight \& Cavusgil, 1996; Oviatt \& McDougall, 1994; Rennie, 1993), entrepreneurship literature continues to explain mainly variations in individual- and firm-level variables associated with early-stage internationalization. Because this approach overlooks important macro-level factors as possible determinants of entrepreneurs' international activities, we propose that economics literature, and particularly research on knowledge spillovers, may be a useful conceptual lens to address the following research question: To what extent are entrepreneurs' international orientations influenced by characteristics of the economic environment in which they are embedded? Specifically, we draw on knowledge spillover literature to examine a particular aspect of entrepreneurs' international orientation: the extent to which they engage in export activities. This focus is consistent with prior research that identifies export as a common entry mode young entrepreneurial firms use to internationalize (e.g., Burpitt \& Rondinelli, 2000; Campbell, 1996; Zahra, Neubaum, \& Huse, 1997).

We argue that two important categories of macro-level factors may serve as determinants of entrepreneurs' export orientation: foreign direct investment (FDI) and international trade. Economics literature indicates these two categories play important roles in shaping a country's economic growth and prosperity. First, inward FDI may contribute to a host country's economic growth by providing employment, capital inflow, and technology spillovers to indigenous firms (Acs, O’Gorman, Szerb, \& Terjesen, 2007; Blomström \& Kokko, 1998). In developing and transition countries in particular, inward FDI offers an important vehicle for economic development (Aitken \& Harrison, 1992; Blomström, 1986; Blomström \& Kokko, 1998; Haddad \& Harrison, 1993; Nevin \& Siotis, 1996; Rivera-Batiz \& Rivera-Batiz, 1991). Second, outward FDI may have a positive impact on an economy through transferring resources gained from foreign market access back to the home country (Dunning, 1993). Third, international trade (i.e., export and import across country borders) upgrades a country's products and services by providing economic actors with access to foreign technology (Blalock \& Veloso, 2005; Glass \& Saggi, 1998; Sjoholm, 1996). Despite these insights provided by economics literature, limited attention is paid to how such international openness may influence the nature of entrepreneurial activity within a country's borders. Accordingly, this study integrates international entrepreneurship and economics research by examining how a country's openness to international activities - as captured by its level of inward and outward FDI, export, and import-may spill over to influence the export orientation of a particular group of its economic actors, specifically, those who recently set up a new business. 
In addition, whereas an increasing body of research investigates factors that drive early-stage internationalization (Autio et al., 2000; De Clercq, Sapienza, \& Crijns, 2005; McDougall et al., 1994), few empirical studies focus on the possible economic contributions of international new ventures. For instance, a few studies investigate the impact of early internationalization on growth and profitability (Autio et al., 2000; Bloodgood et al., 1996; McDougall \& Oviatt, 1996; Zahra, Ireland, \& Hitt, 2000) but typically at the firm level. Therefore, in addition to studying macro-level antecedents of entrepreneurs' export orientation, we focus on a potentially important consequence of entrepreneurs' export orientation and contribute to research on the economic contributions of international new ventures. The second question we address thus is: To what extent may entrepreneurs' export orientation affect their country's total level of (early-stage) entrepreneurial activity? In other words, we examine how a particular aspect of a country's international character-the export orientation of its entrepreneurs-may spill over and encourage the set-up of new businesses within the country's borders. Thus, we also add to literature that suggests entrepreneurial activity itself provides an important source of spillovers (Audretsch \& Keilbach, 2004; Parker, 2005).

\section{THEORETICAL BACKGROUND}

\section{Economics Literature and the Role of Spillovers}

In general terms, economic literature emphasizes the role of knowledge spillovers in the creation of economic growth. The term "spillover" pertains to the transfer of knowledge across economic players; such spillovers may enable important productivity gains (Coe \& Helpman, 1995; Jaffe, Trajtenberg, \& Henderson, 1993; Marshall, 1920). Spillovers allow firms to acquire knowledge from other economic players without having to pay for it in a formal market transaction (Acs, Audretsch, \& Feldman, 1994; Bernstein \& Nadiri, 1988), and according to endogenous growth theory, a country's economic growth stems from the endogenous development of knowledge through spillover effects across economic actors (Romer, 1986).

Spillovers or information externalities occur when people or businesses interact and contain various types of knowledge that may not be understandable or accessible to everyone, such as technological or marketing information. They may take place from one firm to another partially because knowledge represents a public good (Grossman \& Helpman, 1991) or a "non-rival” asset that different economic actors may use simultaneously in different locations (Romer, 1990). Knowledge generally is non-excludable, so knowledge-generating firms have difficulty extracting compensation in return for the use of their knowledge by others (Grossman \& Helpman, 1991). Thus, knowledge-generating firms often cannot fully appropriate or internalize the returns on knowledge investments, and some of these returns spill over to benefit others as well.

In the context of internationalization, knowledge spillovers relate mostly to the proximity of multinational enterprises (MNEs) to other economic actors. Although MNEs possess firmspecific assets, such as superior management know-how or technologies, the non-rival and nonexcludable characteristics of these firm-specific assets challenge their ability to protect some firm-specific advantages; this knowledge likely spills over to other firms in the countries in which they operate (Görg \& Greenaway, 2004; Kneller \& Pisu, 2007). Furthermore, such spillovers may reduce transaction and information costs for other actors in the economy (Caves, 1998) and thus increase their productivity (Görg \& Greenaway, 2004). 
Various researchers examine productivity spillovers across country borders. For instance, Grossman and Helpman (1991) explain that cross-border movements of capital and trade affect economic growth through the related knowledge spillovers. Prior work on the role of spillovers also devotes particular attention to inward FDI, in which knowledge flows from foreign MNEs to the host country's domestic firms, as an important source (e.g., Feinberg \& Majumdar, 2001; Fosfuri, Motta, \& Ronde, 2001). Such research generally assumes MNEs tend to possess superior knowledge when entering foreign markets and therefore compete successfully with local firms in foreign markets (Dunning, 1981; Hymer, 1976), though such knowledge-based assets are difficult for foreign MNEs to internalize fully.

To understand how spillovers occur across country borders and why MNEs find it difficult to protect their knowledge assets, particularly in the case of inward FDI, researchers have identified different spillover channels. First, market access spillovers occur through commercial links between foreign MNEs and local suppliers, which give the local suppliers preferential access to new technological capabilities and foreign customers' product design and quality preferences (Aitken, Hanson, \& Harrison, 1997; Barrell \& Pain 1997; Blomström \& Kokko, 1998). Second, a demonstration or imitation effect prompts domestic firms to copy foreign MNEs' organizational practices, either through formal interfirm collaborations or more informal channels (Wang \& Blomström, 1992). Third, when local employees gain important skills while working for a foreign MNE, a training effect transfers those skills to other organizations (Fosfuri et al., 2001). Fourth, foreign entrants may increase local competition by, for example, infusing new technologies into the local market and thus acting as competitive catalysts (Barrell \& Pain 1997; Cantwell, 1989; Chuang \& Lin 1999; Glass \& Saggi, 1998).

\section{Entrepreneurs and Export Spillovers}

We will argue that these different channels for cross-border spillovers may be helpful for understanding how not only inward FDI but also other sources, such as outward FDI and international trade, influence economy activity within a country's borders. Furthermore, we focus on a specific outcome of cross-border spillovers: the extent to which a country's entrepreneurs engage in export-oriented activities. Export may be particularly difficult for new and small ventures, which often lack the relevant resources (e.g., financial, managerial) to enter international markets (Burpitt \& Rondinelli, 2000; Coviello \& McAuley, 1999; Ogbuehi \& Longfellow, 1994). Export market entry requires upfront sunk costs for firms to sell products or services in foreign markets, such as the costs associated with establishing distribution and logistic channels and acquiring information about the tastes of foreign customers and market structures (Greenaway, Sousa, \& Wakelin, 2004; Requena-Silvente, 2005). Sunk costs are higher for new or small firms, compared with more established counterparts, because they confront resource constraints more directly (Requena-Silvente, 2005).

Spillovers from MNEs may decrease the sunk costs associated with exporting for other economic actors (Aitken et al., 1997; Kneller \& Pisu, 2007), especially through two sources of knowledge (Greenaway et al., 2004). First, knowledge related directly to operating in foreign markets (e.g., consumer tastes, market structures) may be transferred from MNEs to other actors. Second, spillovers may accrue from MNEs to other economic actors through knowledge sources such as technological knowledge or management techniques that improve the competitiveness and ability of other firms to export. Although many studies focus on productivity spillovers (for an overview, see Görg \& Greenaway, 2004 ), literature about the effect of spillovers on the export 
decision of domestic firms (i.e., export spillovers) remains relatively limited (e.g., Aitken et al., 1997; Banga, 2003; Greenaway et al., 2004; Kneller \& Pisu, 2007). Domestic firms may be more inclined to engage in export activities if they are exposed to other economic actors' international activities (Greenaway et al., 2004); Aitken et al. (1997), for instance, note a spillover effect from foreign MNEs to domestic export activity in Mexican manufacturing industries and show that the dominance of foreign MNEs in a particular industry sector increases the probability that domestic firms in the sector also export. Similarly, Greenaway et al. (2004) use U.K. data to show that foreign MNEs' export activities have a positive effect on a domestic firm's export probability.

The study of such export spillover effects is particularly relevant in the context of entrepreneurship, ${ }^{1}$ because emerging firms are more likely to benefit from (external) knowledge spillovers than their more established counterparts (Acs et al., 1994). Whereas in more mature firms, external knowledge spillovers may be less important because they must compete with internal knowledge spillovers from prior and ongoing operations, the knowledge production function of smaller firms (and start-ups in particular) likely gets influenced by input provided by external organizations or activities (Acs et al., 1994). Accordingly, export spillovers should play significant roles in entrepreneurs' decisions to engage in export activities.

\section{HYPOTHESES}

\section{Inward FDI and Entrepreneurs' Export Orientation}

Foreign MNEs (through inward FDI) may act as catalysts of entrepreneurs' involvement in export activities for several reasons. First, foreign MNEs can facilitate export among entrepreneurs through the direct channel established when the latter serve as suppliers or subcontractors for the MNEs. Commercial linkages with foreign MNEs thus provide entrepreneurs with knowledge about new technological developments and foreign market conditions; over time, this knowledge may prompt entrepreneurs' decision to export (Blomström \& Kokko, 1998). Foreign MNEs also pave the way for entrepreneurs to enter the same export markets, either because the MNEs have created adequate transport infrastructures or because they disseminate knowledge about specific foreign markets that the entrepreneurs can use directly. In some cases, foreign MNEs even have an overcapacity with respect to their distribution or marketing facilities, which offers opportunities for (domestic) entrepreneurs.

Second, entrepreneurs exposed to MNE practices through formal alliances or informal exchanges, such as joint memberships in trade associations (Greenaway et al., 2004), may be more likely to engage in export. In this regard, prior research emphasizes imitation as an important mechanism by which knowledge about new product development spills over across economic actors, as exemplified in the practice of reverse engineering that transfers technology across country borders (e.g., Wang \& Blomström, 1992). We extend this rationale to the context of exporting and argue that demonstration or imitation effects may lead entrepreneurs use foreign MNEs as role models for their own decision making (Powell \& DiMaggio, 1991).

Third, spillover effects from foreign MNEs may take place when entrepreneurs acquire human capital. It is difficult for foreign MNEs to lock in their human capital (Djankov \& Hoekman,

\footnotetext{
${ }^{1}$ We use the terms “entrepreneurs," "early-stage entrepreneurs," and "start-ups” synonymously to refer to a new business during its emergence and early years of existence.
} 
1999; Dunning, 1981; Fosfuri et al., 2001), but because they often require a skilled labor force, they organize training for local employees. When those employees move to other firms, they contribute to the diffusion of knowledge in the host country (Gerschenberg, 1987). Similarly, various internationalization skills gained while working for a foreign affiliate may spill over to domestic employees, some of whom decide to leave their foreign employer and start their own new business. Empirical evidence supports the role of prior international experience in entrepreneurs' decision to enter foreign markets (Bloodgood et al., 1996; McDougall et al.,1994; Oviatt \& McDougall, 1995).

Fourth, unless a foreign MNE obtains monopoly status in its host country, inward FDI should lead to increased local competition. Foreign MNEs infuse new technologies into their host countries, and the technology adopted by affiliates can spread to local firms and yield technological benefits (Barrell \& Pain, 1997). Furthermore, foreign affiliates might replace inefficient firms in the host country (Narula \& Marin, 2003). The resultant increased competition should provide local start-ups with the capabilities and need to expand the geographical scope of their activities. That is, the increase in competition that occurs as a result of foreign entry may prompt entrepreneurs to expand their horizons and engage in export activities.

Hypothesis 1: A country's inward flow of FDI relates positively to the export orientation of its entrepreneurs.

\section{Outward FDI and Entrepreneurs' Export Orientation}

Although literature on the impact of FDI on a host country's economic activities focuses mostly on spillover effects stemming from inward rather than outward FDI, domestic MNEs also may affect domestic entrepreneurs' export orientations (Blomström \& Kokko, 1998). The presence of these domestic MNEs in foreign countries may familiarize foreign customers with common business practices in the MNEs' home country, which could create a pull effect on the home country's entrepreneurs (Nagel, 2003). Furthermore, the rationale for the spillover effects of domestic MNEs to entrepreneurs parallels the argument associated with foreign MNEs (Blomström \& Kokko, 1998). First, spillovers may occur if a domestic MNE adapts its products to local conditions abroad and shares this adaptation with its suppliers (e.g., entrepreneurs) in its home country (Aitken et al., 1997). Second, the spillovers obtained through demonstration, training, and competition effects, as outlined in the argumentation leading up to Hypothesis 1, may work in a similar fashion for domestic MNEs. For example, in terms of the training effect, a manager of a foreign subsidiary may return to the home country and become an (export-oriented) entrepreneur (Cantwell \& Hodson, 1991; Kogut \& Chang, 1991). Furthermore, the structural changes that take place in the entrepreneurs' home country because of the wider presence of domestic MNEs (i.e., when there is more outward FDI) may positively influence entrepreneurs' propensity to export. Specifically, an increase in outward FDI should shift the home country toward economic activities that entail greater productivity (Blomström \& Kokko, 1998). This increased productivity may then force entrepreneurs to increase the overall quality of their products, which ultimately should increase their propensity to export.

Hypothesis 2: A country's outward flow of FDI relates positively to the export orientation of its entrepreneurs. 
In addition, we hypothesize that the relative strength of the impact of inward and outward FDI on entrepreneurs' export orientation differs, such that the effect of inward FDI is stronger than that of outward FDI. Although extant literature provides strong support for the role of positive externalities of inward FDI on the host country (e.g., Aitken et al., 1997; Barrell \& Pain, 1997; Greenaway et al., 2004), the effect of outward FDI may be attenuated by a "crowding-out" effect. That is, outward FDI may crowd out the domestic economy, because resources and jobs get transferred to other countries (Jones, 1996). Similarly, outward FDI may crowd out economic activities undertaken by domestic players (Stevens \& Lipsey, 1992), including entrepreneurs' propensity to export, if, for example, the domestic MNEs are significantly more efficient than entrepreneurs in their export activities. This difference in export capabilities should decrease domestic entrepreneurs' tendency to engage in export activities. Therefore, we expect inward FDI has a relatively stronger positive impact on entrepreneurs' export orientation than outward FDI.

Hypothesis 3: A country's flow of inward FDI relates more strongly to the export orientation of its entrepreneurs than does a country's flow of outward FDI.

\section{International Trade and Entrepreneurs' Export Orientation}

In the previous hypotheses, we posit that FDI, both inward and outward, offers an important source of knowledge spillovers; we now also consider how a country's level of international trade may affect the export orientation of its entrepreneurs. We thus extend prior research that indicates a link between international trade (i.e., export and import) and a country's productivity, based on the transfer of knowledge across country borders (Findlay, 1984; Grossman \& Helpman, 1991; Sjoholm, 1996). For example, Findlay (1984) explains that international trade, and in particular the transfer of technology from more to less developed countries, may significantly increase the economic growth of underdeveloped countries. For the purpose of this study, we hypothesize that a country's level of export and import represent two additional sources of knowledge spillovers that influence entrepreneurs' export behavior.

\section{Export}

A country's overall level of export should have a positive effect on the export orientation of its entrepreneurs, particularly through the demonstration effect. That is, simple imitation may play an important role in shaping entrepreneurs' decision to export when they are surrounded by many other firms that also engage in export activities (Greenaway et al., 2004). Furthermore, the positive relationship between a country's export activity and entrepreneurs' export orientation mirrors institutional theory that suggests firm behavior results from mimetic isomorphism, or economic actors' tendency to imitate decisions or practices of peers (Powell \& DiMaggio, 1991).

Spillovers stemming from a country's level of export also may be significant for entrepreneurs because they minimize the challenge of assessing the costs and benefits associated with internationalization, including export activities (Johanson \& Vahlne, 1990). When entrepreneurs come in contact with existing exporters, they gain information about how to become a successful 
exporter more easily, which diminishes their uncertainty regarding the pros and cons of exporting (Burpitt \& Rondinelli, 2000; Ogbuehi \& Longfellow, 1994). For example, information that foreign customers provide to incumbent suppliers regarding how to facilitate the production of goods and services they plan to buy could spill over to entrepreneurs through formal partnerships with exporting firms (e.g., strategic alliances) or more informal channels (e.g., trade associations, publications) (De Clercq et al., 2005; Zahra et al., 2000). The above mentioned training effect may also be relevant in this context; those who directly or indirectly participate in exporting activities receive stimulation to enter foreign markets when they establish their new companies (McDougall et al., 1994). A final mechanism that may explain the positive relationship between a country's overall level of export activity and entrepreneurs' export orientation refers to existing relationships between domestic suppliers and foreign customers, which may create a sense of familiarity among foreign customers regarding the entrepreneurs' country in general and its business practices in particular (Blomström \& Kokko, 1998; Nagel, 2003). This familiarity may increase entrepreneurs' anticipation of success when they consider the possibility of export activities.

Hypothesis 4: A country's export level relates positively to the export orientation of its entrepreneurs.

\section{Import}

We also posit a positive effect between a country's level of import activity and its entrepreneurs' export orientation. Import activity reflects the amount of knowledge exchange that takes place between domestic producers and foreign suppliers. Prior research on spillover effects of import mainly focuses on the role of technology transfer; empirical evidence demonstrates that imports provide an important source for the transfer of new technologies across country borders (e.g., Blalock \& Veloso, 2005; Coe \& Helpman, 1995; Feinberg \& Majumdar, 2001; Glass \& Saggi, 1998). We extend this research by arguing that spillover effects from imports relate to not only technology transfer but also export activities. Entrepreneurs could benefit from their country's import activities if a foreign producer exchanges knowledge about its home market as a sales tool for existing customers (Coe \& Helpman, 1995). If this knowledge spills over to a country's entrepreneurs through their collaborations with and exposure to more knowledgeable domestic players, the entrepreneurs obtain a better understanding of the foreign producers' specific country context and thus achieve a better position to find foreign customers.

In short, foreign producers may reveal information about their own country's unique characteristics as a sales tool, in which case this knowledge accumulates indirectly within the entrepreneurs' country. Over time, the accumulated knowledge about particular countries should decrease uncertainty related to undertaking business activities in foreign countries and enhance entrepreneurs' tendency to engage in export activities.

Hypothesis 5: A country's import level relates positively to the export orientation of its entrepreneurs.

We expect that a country's level of export creates a stronger spillover effect than its level of import because the former provides knowledge specifically targeted at how to sell in foreign 
markets. That is, a spillover effect should be most pronounced when the source and target of spillovers are closely aligned (Coe \& Helpman, 1995). Furthermore, the strong association between entrepreneurs' export orientation and their country's export level may simply relate to entrepreneurs' tendency to imitate the specific behavior of other economic actors with whom they interact in their institutional environment (Powell \& DiMaggio, 1991).

Hypothesis 6: A country's export level relates more strongly to the export orientation of its entrepreneurs than does the country's import level.

\section{Entrepreneurs' Export Orientation and Total Entrepreneurial Activity}

Recent research suggests that entrepreneurial activity results from new knowledge or ideas and specifically the exploitation of knowledge that incumbent firms have not fully appropriated or commercialized (Acs et al., 2006; Acs et al., 2007). When an economic agent with a new idea cannot convince decision makers within an incumbent firm to pursue the idea, the agent may start a new firm in an attempt to appropriate the new knowledge. The new knowledge thus spills over from the agent holding the new knowledge to a new firm in which it is commercialized (Audretsch \& Keilbach, 2004). Hence, in this view, a country's total level of entrepreneurial activity represents an important outcome of spillover effects. Similarly, we suggest that the export orientation of a country's entrepreneurs is not only a consequence of spillover effects - as we hypothesized above - but in turn provides a specific source of spillovers that affects the emergence of new businesses in the country. In other words, entrepreneurs' export orientation is not only an outcome of spillover effects but also a driver of them.

In making this claim, we draw from literature that emphasizes the role of macro-level factors to explain cross-country differences in entrepreneurship (Noorderhaven, Thurik, Wennekers, \& van Stel, 2004; Verheul, Wennekers, Audretsch, \& Thurik, 2002). Specifically, previous literature highlights the roles of supply-side factors (e.g., skills and preferences) in shaping entrepreneurs' willingness or ability to act on new business opportunities and of demand-side factors (e.g., a country's industrial structure or rate of economic growth) to create the opportunities for such start-up activity. A specific supply factor that influences the emergence of new businesses within a country may be the export orientation of its (existing) entrepreneurs for two main reasons. First, exporting entrepreneurs have preferential access to knowledge related to foreign markets and technologies (Autio et al., 2000; Zahra et al., 2000; Hessels, 2007), and this knowledge may generate novel insights into unexploited opportunities for the domestic market (De Clercq et al., 2005; Shane \& Venkataraman, 2000). Second, export-oriented entrepreneurs may act as extraordinary role models for aspiring entrepreneurs (Davidsson \& Honig, 2003). Consequently, and consistent with the premises underlying institutional theory, individual economic actors may imitate the behavior of highly visible and successful peers, including export-oriented entrepreneurs (Powell \& DiMaggio, 1991). Such imitation may then provide support and legitimacy to entrepreneurship as a career choice, resulting in the creation of more new businesses within the country.

Hypothesis 7: The export orientation of a country's entrepreneurs relates positively to its (subsequent) total level of entrepreneurial activity. 


\section{METHODOLOGY}

\section{Data and Sample}

We draw data from various sources. To determine a country's total level of entrepreneurial activity and the export orientation of its entrepreneurs (i.e., dependent variables), we collect information from the Global Entrepreneurship Monitor (GEM; Reynolds et al., 2005). Various organizations (e.g., the WTO, OECD, UN, and Eurostat) publish international comparative statistics about export for many countries, but virtually no official international comparative export statistics to date relate specifically to new ventures. In this respect, the GEM initiative fills an important gap by providing a harmonized measure of the export orientation of early-stage entrepreneurs across countries. For our independent variables, we draw data about a country's FDI from the Foreign Direct Investment database maintained by the United Nations Conference on Trade and Development (UNCTAD) and gather information about each country's export and import levels from the World Bank. Finally, we include several control variables in our models and obtain these data from several sources, including the Global Competitiveness Report and the World Competitiveness Yearbook.

In essence, our data set includes annual data pertaining to 34 countries over a four-year period (2002-2005). The sample of included countries is limited to those that participated in GEM during 2002-2005. ${ }^{2}$ Furthermore, because not all countries participated in GEM in each year and because we note missing data for some independent variables, our analyses are based on 80 observations distributed across 34 countries. The use of such an unbalanced panel in estimating country-level entrepreneurship is consistent with prior research (e.g., Noorderhaven et al., 2004; van Stel and Carree, 2004).

\section{Measures}

\section{Dependent variables}

We measure total level of entrepreneurial activity (2002-2005) using GEM's TEA index, ${ }^{3}$ which assesses the proportion of a country's population between the ages of 18 and 64 years who are either in the start-up phase or manage/own a business that is less than 42 months of age. ${ }^{4}$ The TEA index thus assesses, in a given year, the total level of (early-stage) entrepreneurial activity within a country, irrespective of its nature. Reynolds et al. (2005) provide empirical support for the validity of the TEA index by comparing it with national administrative data on firm birth rates and support its reliability by calculating the correlation of countries' TEA rates over different years.

To measure the export orientation of a country's entrepreneurs (2002-2005), we consider the percentage of a country's (early-stage) entrepreneurs (as defined by the TEA index) involved in substantial export activity. Specifically, we assess the proportion of entrepreneurs, relative to the

\footnotetext{
${ }^{2}$ The countries are Argentina, Australia, Belgium, Brazil, Canada, Chile, China, Denmark, Finland, France, Germany, Greece, Hong Kong, Hungary, Iceland, India, Ireland, Israel, Italy, Japan, Korea, Mexico, Netherlands, New Zealand, Norway, Poland, Slovenia, South Africa, Spain, Sweden, Switzerland, Thailand, United Kingdom, and United States.

${ }^{3}$ The TEA (total early-stage entrepreneurial activity) index is the most widely known index generated by GEM (Minniti, Bygrave, \& Autio, 2006; Reynolds et al., 2005).

${ }^{4}$ We count those engaged in both activities in a given year only once (Reynolds et al., 2005).
} 
total number of entrepreneurs, who stated that at least $26 \%$ of their customers were located in foreign countries (Reynolds et al., 2005). ${ }^{5}$

\section{Independent variables}

Inward FDI (1995-2004) reflects the percentage of a country's inward flow of foreign capital, relative to its gross fixed capital formation. Outward FDI (1995-2004) equals the percentage of a country's outward flow of capital relative to its gross fixed capital formation. We draw both measures from UNCTAD’s World Investment Report.

We use the percentage of a country's exports of goods and services relative to its gross domestic product (GDP) to measure export (1995-2004), which we obtain from the World Development Indicators database, provided by the World Bank. This measure is skewed toward larger and older firms, which undertake the vast majority of export activity (in terms of value added). Particularly in developing countries, the GDP created by small, young firms often is not recorded in official statistics, let alone the amount of their export activity (Reynolds et al., 2005; Sternberg \& Wennekers, 2005). Therefore, it seems unlikely that the added value created by the export activities of young firms, as captured in our GEM-based measure of export orientation, would be recorded in the official statistics about countries' export levels. ${ }^{6}$ Hence, a positive correlation between export as a percentage of GDP and our measure of entrepreneurs' export orientation (in terms of the percentage of foreign customers abroad) is by no means straightforward. Similarly, we measure import (1995-2004) as the percentage of a country's imports of goods and services relative to its GDP. This measure also comes from the World Development Indicators database.

\section{Control variables}

To account for alternative explanations for the variation of both of our dependent variables (i.e., entrepreneurs' export orientation and a country's total level of entrepreneurial activity) across countries, we include several control variables. Consistent with the eclectic framework of entrepreneurship (Verheul et al., 2002), we classify these controls into two categories: (1) demand-side factors that reflect the presence of entrepreneurial opportunities through market demand and (2) supply-side factors that entail the skills and preferences of a country's population toward entrepreneurship.

As demand-side factors, we consider employment share in manufacturing and employment share in services (2000) to represent a country's economic structure, which may influence the level and nature of the country's entrepreneurial activity (Verheul et al., 2002). We draw this measure from the World Competitiveness Yearbook. In addition, we use a poor country dummy (2000) to reflect a country's overall prosperity, which may influence its start-up activities (Verheul et al., 2002). We code this dummy as 1 when per capita income in 2000 exceeded US\$15,000 in purchasing power parity and 0 otherwise. This measure also comes from the World Competitiveness Yearbook. To assess the annual percentage change in a country's GDP, a dynamic measure of a country's overall prosperity, we use economic growth (2002-2005), based

\footnotetext{
${ }^{5}$ The lack of cross-country data on export activity undertaken by early-stage entrepreneurs makes it infeasible to compare this measure with existing scales.

${ }^{6}$ Part of the TEA index relates to nascent entrepreneurs, who have not yet started their business (Reynolds et al., 2005); thus, for this group of entrepreneurs, official export statistics certainly do not capture (expected) export activity.
} 
on data from the World Economic Outlook database, provided by the International Monetary Fund. Finally, our measure of company-university cooperation (2001) assesses (on a seven-point Likert scale) the technology transfer between companies and universities and reflects a source of technological resources for entrepreneurs. This measure emerges from the World Competitiveness Yearbook.

In terms of supply-side factors, ease of access to loans (2001), measured on a seven-point Likert scale and drawn from the Global Competitiveness Report, reflects the extent to which (potential) entrepreneurs have easy access to financial resources to support their activities. Furthermore, tertiary education (1997), also drawn from the Global Competitiveness Report, pertains to a country's gross tertiary enrollment rate.

For the estimation of entrepreneurs' export orientation, we also include three additional control variables: gross domestic product (logarithm) (2002-2005), drawn from the World Development Indicators database, which reflects the size of a country's home market; inflation rate (20022005), obtained from the World Economic Outlook Database, which reflects increases in consumer price levels (annual percentage changes) that may make it harder for economic actors to engage in export activity (domestically, inflation often coincides with wage compensations, but such compensation is less likely at the international trade level), and change in exchange rate (2002-2005), drawn from Economic History Services (and supplemented by OANDA.com), is the percentage change of a country's national currency in U.S. dollars. When the exchange rate increases, products become relatively more expensive for foreign buyers, which may hinder entrepreneurs' export orientation.

Finally, we include time dummies to control for temporal changes in the global economic environment that may influence the level and nature of entrepreneurial activity within countries.

We test our hypotheses using regression analyses. To avoid reverse causality and account for the possibility that knowledge spillovers may take some time before they materialize (Jaffe \& Trajtenberg, 1998), we use different time lags in the analyses. However, six controlsemployment share of manufacturing, employment share of services, poor country dummy, company-university cooperation, ease of access to loans, and tertiary education-represent timeinvariant variables because they reflect structural characteristics of an economy and thus change only slowly over time.

\section{RESULTS}

In Table 1, we display the correlations among the study variables. The correlations between entrepreneurs' export orientation and the four (one-year lagged) sources of cross-border spillovers (inward FDI, outward FDI, export, and import) are significant and positive; however, we also note the high correlation coefficients between the four variables, particularly between a country's export and import levels (.98), which raises concerns about multicollinearity (Greene, 2004). Accordingly, in the regression analysis, we enter the four variables in separate models (Table 2).

We first include the control variables in a model that estimates the export orientation of a country's entrepreneurs (Model 1). Entrepreneurs' export orientation is positively influenced by their country's employment share in manufacturing and services but negatively by GDP (logged) and inflation rate. Models 2-5 show the results when we enter the four sources of export 
spillovers (i.e., inward FDI, outward FDI, export, and import, respectively) with one-year time lags. Although inward FDI does not affect entrepreneurs' export orientation, we find a positive effect for outward FDI $(p<.05)$ and export and import $(p<.01)$. To test the combined effect of these three (significant) sources of knowledge spillovers, we include a country's outward FDI and total international trade (i.e., export plus import) in Model 6. (The very high correlation between countries' export and import levels suggests this combined variable is warranted.) The results in Model 6 suggest no effect of outward FDI but a strong effect of international trade $(p<$ $.01)$. Finally, to assess whether a country's export level has a stronger effect than its import level on entrepreneurs' export orientation (Hypothesis 6), we include a variable assessing a country's international trade surplus (i.e., export minus import) in Model 7; the effect of this variable is not significant, so we find no support for a differential effect of export versus import.

In summary, the findings in Table 2, in which we use one-year time lags, offer tentative support for Hypothesis 2 (i.e., a positive effect of outward FDI in Model 3 that disappears when we account for the effect of international trade in Model 6) and strong support for Hypotheses 4 and 5 (i.e., positive effects of export and import in Models 4 and 5 and of international trade in Models 6 and 7). The effect of export and import is stronger than that of outward FDI, but we find no differential effect between export and import in Model 7 (i.e., no support for Hypothesis 6). Finally, we find no support for Hypothesis 1 (no individual effect of inward FDI) and therefore no support for Hypothesis 3 (i.e., compared with inward FDI, outward FDI has a stronger rather than weaker effect on entrepreneurs' export orientation).

Insert Tables 1 and 2 about here

To determine whether export spillover effects may manifest themselves differently over time, we ran several models with different time lags, ranging from two to seven years (i.e., $\mathrm{t}-2$ to $\mathrm{t}-7$ ). As we report in Table 3 (Models 8-10), the results for a set of statistically optimal time lagsi.e., those lags that are associated with the strongest effect of a specific source of spilloverindicate positive effects of both inward FDI (Model 8, $p<.05$, three-year time lag) and outward FDI (Model 9, $p<.01$, six-year time lag) on entrepreneurs' export orientation. Furthermore, in Model 10, in which we combine the export and import variables into a total international trade variable, we find a strong effect of total international trade on entrepreneurs' export orientation with a three-year time lag $(p<.01)$. Finally, Model 11 includes inward FDI, outward FDI, total international trade, and international trade surplus as predictors of entrepreneurs' export orientation. Although the surplus variable is not significant, the effect of total international trade is marginally significant $(p<.10)$, and we find the strongest effect for outward FDI (i.e., $p<$ $.01)$.

Insert Table 3 about here

When we compare the results of Table 3 (longer time lags) with Table 2 (one-year time lags), two observations emerge. First, we find no spillover effect of inward FDI in the short term 
(Table 2, Model 2), and although a country's flow of inward FDI positively influences the export orientation of its entrepreneurs after three years (Table 3, Model 8), its effect disappears when we account for the other sources of knowledge spillovers (i.e., the significant effect of inward FDI in Model 8 disappears in Model 11). Overall, we thus find very weak support for a knowledge spillover effect from inward FDI to entrepreneurs' export orientation. Second, in the short term, the effect of international trade appears to be stronger than that of outward FDI, but the opposite occurs when considering longer periods of time. That is, the effect of international trade dominates in the short term (Table 2, Model 7), whereas the effect of outward FDI dominates in the long term (Table 3, Model 11).

Finally, we report the results related to a country's total level of entrepreneurial activity in Table 4. ${ }^{7}$ Model 12, which includes only the controls, shows that a country's economic growth and tertiary education enrollment rate positively influence new business creation, whereas employment share in manufacturing has a negative effect. When we add entrepreneurs' export orientation in Model 13, we observe no significant effect, but as Tables 2 and 3 and our hypotheses suggest, the export orientation variable is not exogenous. In particular, the log of GDP (i.e., size of the home market) has a strong impact on entrepreneurs' export orientation, and therefore, the ordinary least squares estimates in Model 13 likely are biased (Greene, 2004). Accordingly, in Model 14, we estimate a country's total level of entrepreneurial activity using the instrumental variable estimation technique (Greene, 2004). ${ }^{8}$ Consistent with our expectations in Hypothesis 7, we find a positive, albeit weak, effect of entrepreneurs' export orientation on the total level of entrepreneurial activity within their country $(p=.06)$. Furthermore, we note that the inclusion of insignificant variables in our model creates a small upward bias in our standard errors. For example, when we exclude the year dummies - which do not appear in the tables for parsimony-we find that the significance level of the export orientation variable in Model 14 changes to .04, which further corraborates Hypothesis 7. We also note that the relatively weak effect of entrepreneurs' export orientation on total entrepreneurial activity may be partially due to our use of a one-year time lag in Table 4; because data about entrepreneurs' export orientation were collected by the GEM as recently as 2002, only a limited number of data points are available for this variable, and the use of longer time lags is therefore not feasible.

Insert Table 4 about here

\section{DISCUSSION}

Extant literature suggests that firms' entry into foreign markets can be very difficult, especially for early-stage companies that lack necessary resources, such as first-hand information about

\footnotetext{
${ }^{7}$ The number of observations in Table $4(\mathrm{~N}=75)$ differs from Tables 2 and $3(\mathrm{~N}=80)$. The one-year time lag used in Table 4 results in a loss of observations for the export orientation variable, but Table 4 also "gains" observations for which a spillover variable (i.e., FDI, international trade) was missing in Tables 2 and 3.

${ }^{8}$ In Model 14, the number of instruments equals the number of endogenous explanatory variables (i.e., 1), so the model is exactly identified (Greene, 2004). As a robustness test we tried several alternative estimations, with FDI and the trade variables as additional instruments. All estimations support the validity of the applied instruments, and the coefficient for the export orientation variable remains similar to that reported in Model 14 (Table 4).
} 
foreign tastes and distribution channels (Autio et al., 2000; Eriksson, Johanson, Majkgard, \& Sharma, 1997; McDougall \& Oviatt, 2000). We extend international entrepreneurship literature that typically examines the role of individual- or firm-level factors on entrepreneurs' international activities by considering the effect of macro-level (i.e., country) variables. To this end, we rely on knowledge spillovers literature to argue that cross-country differences with respect to entrepreneurs' export orientation may be the result of a country's openness to crossborder activities (Grosmann \& Helpman, 1991), as reflected in its level of FDI (both inward and outward) and international trade (export and import). In addition, we consider entrepreneurs' export orientation not only a consequence of knowledge spillovers but also a driver of entrepreneurship spillovers that contribute to the overall emergence of new businesses within a country’s borders (Audretsch \& Keilbach, 2004; Parker, 2005).

Our results generally support the role of spillover effects in shaping the propensity of a country's entrepreneurs to engage in export activities. Specifically, a country's outward FDI, export, and import activities positively influence entrepreneurs' export orientation; whereas the effect of export and import (i.e., international trade) dominates outward FDI in the short term, the opposite is true in the long term. However, the effect of inward FDI appears nonexistent when the other sources of spillovers come into play. Finally, we find support for the spillover effect of export-oriented entrepreneurship on a country's overall level of entrepreneurial activity.

First, contrary to our expectations, we do not find evidence of a positive influence of a country's inward FDI on the export orientation of its entrepreneurs. This finding is revealing, because significant economics literature concentrates on the role of foreign MNEs for creating economic prosperity within host countries (e.g., Barrell \& Pain, 1997) or increasing domestic firms' propensity to export (Aitken et al., 1997; Greenaway et al., 2004). However, this source of spillover does not appear to affect the export orientation of a host country's entrepreneurs, perhaps because the channels for knowledge spillovers from inward FDI seem more relevant to incumbent economic players than to recently created firms. Foreign MNEs may be likely to establish commercial linkages with local players that have certain reputations in the host country rather than with novices that lack legitimacy (Podolny, 1993). Alternatively, early-stage companies may have limited capacity to absorb the knowledge provided by foreign MNEs (Cohen \& Levinthal, 1990) and therefore benefit less from their cooperation. It could also be that the extent to which foreign MNEs are able to internalize the returns on knowledge investments is larger than has been hitherto assumed. These explanations are somewhat speculative; further research should assess in more detail the intermediate mechanisms through which entrepreneurs benefit, or fail to benefit, from inward FDI, as well as how these mechanisms may differ for early-stage versus more mature companies.

Second, the positive influence of a country's outward FDI on the export orientation of its entrepreneurs is revealing in the light of the argument, upheld by some researchers, that outward FDI can harm a country's economic prosperity by transferring local production and employment to foreign countries (e.g., Jones, 1996). Our study indicates that outward FDI may benefit a country's economic activity by stimulating entrepreneurs' involvement in export-oriented activities. This positive spillover, as we hypothesized, may occur because domestic MNEs in foreign markets create pull effects (Nagel, 2003), from which domestic entrepreneurs benefit. Overall, our results with regard to the positive effect of outward FDI match prior research that highlights the beneficial role of outward FDI in providing technological feedback to the home country (Dunning, 1993), as well as empirical results regarding the positive spillover effects of 
outward FDI to domestic firms (Blomström \& Kokko, 1998; Popovici, 2005). Our results also reveal that the export spillover effects from outward FDI may not materialize immediately but rather take time before they influence entrepreneurs' decision to engage in exporting. In this regard, prior research suggests that because outward FDI implies an investment of both money or capital flows and other resources, such as management expertise, it may take some time before the investing firm benefits from FDI (Jones, 1996). Similarly, our study indicates it may take time before spillovers from domestic MNEs, such as providing human capital or functioning as role models, influence entrepreneurs’ export decisions (Jaffe \& Trajtenberg, 1998).

Third, in the short term, the strongest source of export spillovers is the country's international trade (export and import). Consistent with institutional theory (Powell \& DiMaggio, 1991), economic actors have an inclination to imitate the behavior and practices to which they can relate more directly. Although we argued that the channels through which export spillovers occur work to a great extent in similar ways when they stem from FDI versus international trade (e.g., the role of commercial linkages), entrepreneurs may consider FDI a more "distant” and therefore less attainable economic activity. Consequently, their short-term decisions with respect to exporting may be influenced more strongly by their exposure to "simple" international trade rather than complex FDI activities (Powell \& DiMaggio, 1991). In this regard, we also highlight our finding that a country's level of import has an equally strong spillover effect on entrepreneurs' export orientation as its level of export. Prior research suggests that at the firm level, import and export activities often go hand in hand (Fletcher, 2001), and that import provides an important determinant of export activity (Lefebvre \& Lefebvre, 2002). That is, the hurdle to engage in exporting may lower significantly when the company already has established business contacts in foreign countries through its import activities. Our findings suggest such connections may also exist at the country level and actually spill over across firms. More specifically, the knowledge gained through import activities undertaken by a country's incumbent economic players may spill over to other economic actors, including entrepreneurs with international ambitions.

Fourth, in terms of the effect of entrepreneurs' export orientation on the subsequent emergence of new companies, we find support for the thesis that people tend to establish their own businesses when their country is characterized by a high prevalence of export-oriented entrepreneurship. Export-oriented entrepreneurs may act as successful role models for aspiring entrepreneurs and thus function as catalysts for others to start their own firms (Davidsson \& Honig, 2003; De Clercq \& Arenius, 2006). In this sense, we identify a particular type of entrepreneurship spillover that stems from export-oriented entrepreneurship (Parker, 2005). This finding also extends prior research that has sought to understand the determinants of a country's level of entrepreneurship (e.g., Gavron, Cowling, Holtham, \& Westall, 1998; Noorderhaven et al., 2004; Storey, 1999; Thurik \& Wennekers, 2004; van Stel, Carree, \& Thurik, 2005). To the best of our knowledge, our study is among the first to examine the link between a country's level and type of entrepreneurial activity. The type of entrepreneurial activity chosen by entrepreneurs clearly has important implications for an economy (Baumol, 1990), including the greater productivity of exporting firms compared with non-exporting firms (Castellani, 2002; Girma, Greenaway, \& Kneller, 2004). Our study suggests that an important mechanism through which entrepreneurs' export activities could affect economic prosperity at the country level is through the positive spillover effect on other economic actors' decision to launch a new business. 


\section{Limitations and Future Research}

Although this study provides important insights into what determines the export orientation of a country's entrepreneurs (and its overall level of entrepreneurial activity), it also includes some limitations. These limitations, in turn, open avenues for future research.

First, we focus on only one particular aspect of productive activity among entrepreneurs (Baumol, 1990), namely, the extent to which they engage in substantial export activity. Although export represents an important dimension of entrepreneurs' international activities (e.g., Burpitt \& Rondinelli, 2000; Johanson \& Vahlne, 1990), it would be interesting to examine knowledge spillover effects on other facets of international involvement, such as foreign licensing, franchising, or even FDI (Eriksson et al., 1997). Furthermore, the vast body of research on the impact of technology spillovers on economic growth (e.g., Blalock \& Veloso, 2005; Feinberg \& Majumdar, 2001; Glass \& Saggi, 1998) offers a means for entrepreneurship researchers to include alternative dimensions of productive activities (e.g., innovation) that result from FDI and international trade. Such an approach would provide a more encompassing view of how countries' openness to internationalization influences entrepreneurs' potential contribution to economic prosperity.

Second, our data set covers only a relatively short period of time, particularly as regards the variables drawn from GEM, so our analyses are largely static. Additional research would benefit greatly from longitudinal data that span a longer period of time and thus incorporate dynamic elements into the hypothesized relationships. In particular, further research could use time lags greater than a year to examine the spillover effect of entrepreneurs' export orientation on future entrepreneurial activity, because such spillovers may manifest themselves more strongly over time.

Third, in the theory and hypotheses sections, we discussed several channels through which spillovers may occur for entrepreneurs who aspire to engage in export activities (e.g., commercial linkages, prior employment with foreign firms). However, we do not empirically measure these channels. Although the intangible nature of export spillovers makes an empirical assessment of the channels through which these spillovers operate challenging (Greenaway et al., 2004), research should provide more insight into the specific effects generated by various types of spillover channels on entrepreneurs' export orientation. Moreover, the importance of different spillover channels may be contingent on the specific source of the spillovers (e.g., FDI versus international trade).

Fourth, because we focus on aggregate country-level spillover effects, we may have omitted some important industry-level effects. Literature on technology spillovers traditionally focuses on the industry level (e.g., Bernstein \& Nadiri, 1988; Cohen \& Klepper, 1996), including the large body of research examining whether spillovers within versus between industries are more effective for economic growth (e.g., Frenken, van Oort, \& Verburg, 2007; Glaeser, Kallal, Scheinkman, \& Shleifer, 1992; Jacobs, 1969; van Stel \& Nieuwenhuijsen, 2004). Similarly, in the context of our study, entrepreneurs' decisions to engage in export activities may depend on knowledge flows from other companies active in the same sector of the economy. By ignoring industry-specific factors, we implicitly assume that the mechanisms through which export spillovers work for entrepreneurs are identical across industries. Additional research could examine the extent to which the strength of spillover effects on entrepreneurs' export practices depends on important industry characteristics, such as maturity level or competition. Finally, researchers could compare the effect of vertical spillovers (i.e., between suppliers and buyers 
within an industry) versus horizontal spillovers (i.e., between equals across industries) on entrepreneurs' export decisions.

\section{Implications}

This study also offers some practical implications. First, entrepreneurs who want to become important players in the international arena should locate in areas where other international players are concentrated. From a country-level perspective, governments that hope to encourage export activities among entrepreneurs may benefit from creating geographical zones specifically reserved for internationally oriented firms (Din, 1994). Our findings imply that such zones may help reduce entrepreneurs' costs of breaking into foreign markets.

Second, governments traditionally focus on stimulating export activity among domestic firms and attracting inward FDI to generate economic growth (Ghauri \& Oxelheim, 2003; Greenaway et al., 2004; Molnar, 2003). Furthermore, even when national instruments for promoting import and outward FDI exist, they tend to be part of the development policy of poorer or less developed countries (Hessels \& Prince, 2005). Our study suggests that irrespective of a country's level of development, domestic economies benefit if governments promote import activity and outward FDI. That is, an increased international trade (both export and import) and outward FDI stimulate entrepreneurs' involvement in export activities, which could ultimately foster economic prosperity (Hessels \& van Stel, 2007). Governments might thus benefit from further reducing existing trade and investment barriers and create specific support measures to promote FDI and international trade.

\section{Conclusion}

We examine the role of a country's foreign direct investment and international trade as sources of spillover effects on entrepreneurs' export decisions, as well as a means to spur a country's total level of entrepreneurial activity. Our study highlights that entrepreneurs' export orientation functions as a catalyst for new businesses within a country's borders; export orientation itself is influenced by a country's levels of outward FDI and international trade. Therefore, this article reveals that literature on spillovers provides a useful lens for studying macro-level antecedents and outcomes of entrepreneurs' involvement in international activities. We hope then that this study leads to the further investigation of the fundamental mechanisms by which a country's posture in terms of its international activity may affect the nature and outcomes of its entrepreneurs' undertakings. 


\section{REFERENCES}

Acs, Z.J., Audretsch, D.B., Braunerhjelm, P. and Carlsson, B. 2006. The Knowledge Spillover Theory of Entrepreneurship, CESIS Electronic Working Paper Series, Paper No. 77.

Acs, Z.J., Audretsch, D.B., and Feldman, M. 1994. R\&D spillovers and recipient firm size. American Economic Review 78: 678-688.

Acs, Z.J., O’Gorman, C., Szerb, L., and Terjesen, S. 2007. Could the Irish miracle be repeated in Hungary? Small Business Economics, 28(2/3): 123-142.

Aitken, B., Hanson, G.H., and Harrison, A.E. 1997. Spillovers, foreign investment and export behavior. Journal of International Economics 43: 103-132.

Aitken, B., and Harrison, A.E. 1992. Does proximity to foreign firms induce technology spillovers? PRD Working Paper. Washington: World Bank.

Audretsch, D.B., and Keilbach, M. 2004. Entrepreneurship capital and economic performance, Regional Studies, 38: 949-959.

Autio, E., Sapienza, H.J., and Almeida, J.G. 2000. Effects of age at entry, knowledge intensity, and imitability on international growth. Academy of Management Journal 43(5): 909924.

Banga, R. 2003. Differential Impact of Japanese and U.S. Foreign Direct Investments on Exports of Indian Manufacturing, Working paper, Delhi School of Economics, India.

Barrell, R., and Pain, N. 1997. Foreign direct investment, technological change, and economic growth within Europe. The Economic Journal 107: 1770-1786.

Baumol, W.J. 1990. Entrepreneurship: productive, unproductive and destructive. Journal of Political Economy 98(5): 893-921.

Bernstein, J.I., and Nadiri, M. 1988. Interindustry R\&D spillovers, rates of return, and production in high-tech Industries. American Economic Review 78(2): 429-434.

Blalock, G., and Veloso, F. 2005. Trade, technology transfer and productivity growth: The neglected role of imports. Working Paper, Cornell University.

Blomström, M. 1986. Foreign investment and productive efficiency: the case of Mexico, Journal of Industrial Economics 35: 97-110.

Blomström, M., and Kokko, A. 1998. Multinational corporations and spillovers. Journal of Economic Surveys 12(2): 1-31.

Bloodgood, J.M., Sapienza, H.J., and Almeida, J.G. 1996. The internationalization of new highpotential U.S. ventures: antecedents and outcomes, Entrepreneurship Theory and Practice 20(4): 61-76.

Burpitt, W.J., and Rondinelli, D.A. 2000. Small firms' motivations for exporting: To earn and learn? Journal of Small Business Management 38, 1-14.

Campbell, A.J. 1996. The effects of internal firm barriers on the export behavior of small firms in a free trade environment,' Journal of Small Business Management 34, 50-58.

Cantwell, J. 1989. Technological innovation and multinational corporations. Basil Blackwell, Oxford.

Cantwell, J., and Hodson, C. 1991. Global R\&D and UK competitiveness. In M. Casson (ed.), Global Research Strategy and International Competitiveness. Oxford and Cambridge; Basil Blackwell.

Castellani, D. 2002. Export behavior and productivity growth: evidence from Italian manufacturing firms. Weltwirtschafliches Archiv 138: 605-628. 
Caves, R.E. 1998. Research on international business: problems and prospects, Journal of International Business Studies 29 (1): 5-19.

Chuang, Y. C., and Lin, C. M. 1999. Foreign direct investment, R\&D and spillover efficiency: Evidence from Taiwan's manufacturing firms. Journal of Development Studies 35: 117137.

Coe, D., and Helpman, E. 1995. International R\&D spillovers. European Economic Review 39(5): 859-887.

Cohen, W.M., and Klepper, S. 1996. Firm size and the nature of innovation within industries: the case of process and product R\&D. The Review of Economics and Statistics 78: 232-243.

Cohen, W.M, and Levinthal, D.A. 1990. Absorptive capacity: a new perspective on learning and innovation. Administrative Science Quarterly 35: 128-152.

Coviello, N.E. and McAuley, A. 1999. Internationalisation and the smaller firm: a re-view of contemporary empirical research, Management International Review, 39 (3): 223-256.

Davidsson, P., and Honig, B. 2003. The role of social and human capital among nascent entrepreneurs. Journal of Business Venturing 18: 301-330.

De Clercq, D., \& Arenius, P. 2006. The role of knowledge in business start-up activity. International Small Business Journal, 24(4): 339-358.

De Clercq, D., Sapienza, H.J., \& Crijns, H. 2005. The internationalization of small and mediumsized firms: The role of organizational learning effort and entrepreneurial orientation. Small Business Economics, 24(4): 409-419.

Din, M. 1994. Export processing zones and backward linkages. Journal of Development Economics 43(2): 369-385.

Djankov, S., and Hoekman, B. 1999. Foreign investment and productivity growth in Czech enterprises. World Bank Economic Review 14: 49-64.

Dunning, J.H. 1981. International Production and the Multinational Enterprise, London: George Allen\& Unwin.

Dunning, J. 1993. The Globalization of Business. Routledge, London.

Eriksson, K., Johanson, J, Majkgård, A., and Sharma, D.D. 1997. Experiential knowledge and cost in the internationalization process. Journal of International Business Studies 28: 337-360.

Feinberg, S., and Majumdar, S.K. 2001. Technology spillovers from foreign direct investment in the pharmaceutical industry. Journal of International Business Studies 32 (3): 421-438.

Findlay, R. 1984. Growth and development in trade models. In Handbook of International Economics, Volume 1: International Trade. R. Jones and P. Kenen (eds.), North-Holland, New York, pp. 185-236.

Fletcher, R. 2001. A holistic approach to internationalisation, International Business Review 10: 25-49.

Fosfuri, A., Motta, M., and Rønde, T. 2001. Foreign direct investment and spillovers through workers' mobility. Journal of International Economics 53: 205-222.

Frenken, K., van Oort, F.G., and Verburg, T. 2007. Related variety, unrelated variety and regional economic growth. Regional Studies, forthcoming.

Gavron, R., Cowling, M., Holtham, G., and Westall, A. 1998. The Entrepreneurial Society. London: Institute for Public Policy Research.

Gerschenberg, I. 1987. The training and spread of management know-how: A comparative analysis of multinational and other firms in Kenya. World Development 15: 931-939. 
Ghauri, P. \& Oxelheim L. 2003. European Union and the Race for Foreign Direct Investment in Europe. Oxford: Elsevier.

Girma, S., Greenaway, D., and Kneller R. 2004. Does exporting lead to better performance? A microeconomic analysis of matched firms. Review of International Economics 12(5): 855-866.

Glaeser, E.L., Kallal, H.D., Scheinkman, J.A., and Shleifer, A. 1992. Growth in cities. Journal of Political Economy 100: 1126-1152.

Glass, A., and Saggi, K. 1998. International technology transfer and the technology gap. Journal of Development Economics 55: 369-398

Görg, H. and Greenaway, D. 2004. Much ado about nothing? Do domestic firms really benefit from foreign direct investment? The World Bank Research Observer 19 (2): 171-197.

Greenaway D., Sousa N., and Wakelin K. 2004. Do domestic firms learn to export from multinationals? European Journal of Political Economy 20(4): 1027-1043.

Greene, W. 2004. Econometric Analysis, 5th Edition, Prentice Hall: New York.

Grossman, G.M., and Helpman, E. 1991. Trade, knowledge spillovers, and growth European Economic Review 35(2-3): 517 - 526.

Haddad, M., and Harrison, A. 1993. Are there positive spillovers from direct foreign investment? evidence from panel data for Morocco. Journal of Development Economics 42(5): 1-74.

Hessels, S.J.A. 2007. Innovation and international involvement of Dutch SMEs. International Journal of Entrepreneurship and Small Business, 4(3): 234-255.

Hessels, J., and Prince, Y. 2005. International comparison of the internationalisation of SMEs. Working Paper, EIM, Zoetermeer.

Hessels, S.J.A. and van Stel, A.J. 2007. Export Orientation among New Ventures and Economic Growth, ERIM Report Series 2007-008.

Hymer, S.H. 1976. The international operations of national firms: a study of direct foreign investment, Boston: MIT Press.

Jacobs, J. 1969. The Economy of Cities, New York: Vintage.

Jaffe, A.B., and Trajtenberg, M. 1998. International knowledge flows: Evidence from patent citations, NBER Working Paper No. 6507, April 1998.

Jaffe, A., Trajtenberg, M., and Henderson, R. 1993. Geographical localization of knowledge spillovers as evidenced by patent citations' Quarterly Journal of Economics 108(3): 577 599.

Johanson, J., and Vahlne, J.E. 1990. The mechanism of internationalization. International Marketing Review 7: 11-24.

Jones, G. 1996. The Evolution of International Business. London/New York: Routledge.

Keeble, D., Lawson, C., Smith, H., Moore, B. and Wilkinson, F. 1998. Internationalisation processes, networking and local embeddedness in technology-intensive small firms, Small Business Economics, 11(4): 327-342.

Kneller, R. and Pisu, M. 2007. Industrial linkages and export spillovers from FDI, The World Economy 30 (1): 105-134.

Knight, G., and Cavusgil, S.T. 1996. The born global firm: A challenge to traditional internationalisation theory. Advances of International Marketing 8: 11-26.

Kogut, B., and Chang, S.J. 1991. Technological capabilities and Japanese foreign direct investment in the United States. Review of Economics and Statistics 41: 401-414.

Lefebvre, E., and Lefebvre, L.-A. 2002. Innovative capabilities as determinants of export performance and behaviour: A longitudinal study of manufacturing SMEs, in: 
Kleinknecht, A. and Mohnen, P. 2002. Innovation and firm performance: econometric explorations of survey data, London: Palgrave.

Marshall, A. 1920. Principles of Economics, London: Macmillan.

McDougall, P.P. and Oviatt, B.M. 1996. New venture internationalization, strategic change, and performance: a follow-up study, Journal of Business Venturing, 11: 23-40.

McDougall, P.P., and Oviatt, B.M. 2000. International entrepreneurship: The intersection of two paths. Academy of Management Journal 43: 902-906.

McDougall, P.P., Shane, S., and Oviatt, B.M. 1994. Explaining the formation of international new ventures: The limits of international business research. Journal of Business Venturing 9: 469-487.

Minniti, M, Bygrave, W., and Autio, E. 2006. Global Entrepreneurship Monitor: 2005 Executive Report. London Business School and Babson College. London, U.K., and Babson Park, MA.

Molnar, K. 2003. Australian Export Promotion in a Global Era. Working Papers GOV2003-3, The University of Sydney.

Nagel, A. 2003. Beyond Knut Holt's fusion model: Balancing market pull and technology push. International Journal of Technology Management 25(6/7): 614-622.

Narula, R., and Marin, A. 2003. FDI-spillovers, absorptive capacities and human capital development: evidence from Argentina. MERIT-Infonomics Research Memorandum series.

Nevin, D., and Siotis, G. 1996. Technology sourcing and FDI in the EC: An empirical evaluation. International Journal of Industrial Organization 14: 543-560.

Noorderhaven, N., Thurik, A.R., Wennekers, A.R.M., and van Stel, A.J. 2004. The role of dissatisfaction and per capita income in explaining self-employment across 15 European countries. Entrepreneurship Theory and Practice 28(5): 447-466.

Ogbuehi, A.O. and T.A. Longfellow (1994). Perceptions of U.S. manufacturing SMEs concerning exporting: a comparison based on export experience. Journal of Small Business Management, 32: 37-47.

Oviatt, B. and McDougall, P. 1994. Toward a theory of international new ventures, Journal of International Business Studies 25 (1): 45-62.

Oviatt, B.M. and McDougall, P.P. 1995. Global start-ups: entrepreneurs on a worldwide stage, The Academy of Management Executive 9 (2): 30-44.

Parker, S.C. 2005. The economics of entrepreneurship: what we know and what we don't. Foundations \& Trends in Entrepreneurship 1(1): 1-55

Podolny, J.M. 1993. A status-based model of market competition. American Journal of Sociology 98: 829-872.

Popovici, I. 2005. Outward R\&D and Knowledge spillovers: evidence using patent citations. No 516, Working Papers from Florida International University, Department of Economics.

Powell, W.W., and DiMaggio, P.J. 1991. The new institutionalism in organizational analysis. The University of Chicago Press.

Rennie, M.W. 1993. Global competitiveness: born global, The McKinsey Quarterly 4: 45-52.

Reynolds, P., Bosma, N., Autio, E., Hunt, S., De Bono, N., Servais, I., Lopez-Garcia, P., and Chin, N. 2005. Global Entrepreneurship Monitor: data collection design and implementation 1998-2003. Small Business Economics 24(3): 205-231.

Requena-Silvente, F. 2005. The decision to enter and exit foreign markets: evidence from UK SMEs, Small Business Economics, 25(3): 237-253. 
Rivera-Batiz, F.L., and Rivera-Batiz, L.A. 1991. The effects of direct foreign investment in the presence of increasing returns due to specialization. Journal of Development Economics 34: 287-307.

Romer, P., 1986. Increasing returns and long-run growth. Journal of Political Economy 94: 1002-1037.

Romer, P. 1990. Endogenous technological change, Journal of Political Economy, 98 (5): S71S102.

Sapienza, H.J., De Clercq, D., and Sandberg, W.R. 2005. Antecedents of international and domestic learning effort. Journal of Business Venturing 20(4): 437-457.

Shane, S. \& Venkataraman, S. 2000. The promise of entrepreneurship as a field of research. Academy of Management Review, 25: 217-226.

Sjoholm, F. 1996. International transfer of knowledge. The role of international trade and geographic proximity. Weltwirtschaftliches Archiv, 132: 97-115.

Sternberg, R., and Wennekers, A.R.M. (2005) Determinants and effects of new business creation: investigations using Global Entrepreneurship Monitor data. Small Business Economics, 24(3): 205-231.

Stevens, G.V.G., and Lipsey, R.E. 1992. Interactions between domestic and foreign investment. Journal of Money and Finance, 11: 40-62.

Storey, D.J. 1999. Six steps to heaven: evaluating the impact of public policies to support small business in developed economies, in: D.L. Sexton and H. Landström (eds.), Handbook of Entrepreneurship, Oxford: Blackwell, 176-194.

Thurik, A.R., and Wennekers, A.R.M. 2004. Entrepreneurship, small business and economic growth. Journal of Small Business and Enterprise Development 11(1): 140-149.

Van Stel, A.J., and Carree, M.A. 2004. Business ownership and sectoral growth: An empirical analysis of 21 OECD countries. International Small Business Journal 22 (4): 389-419.

Van Stel, A.J., Carree, M., and Thurik, A.R. 2005. The effect of entrepreneurial activity on national economic growth. Small Business Economics 24: 311-321.

Van Stel, A.J., and Nieuwenhuijsen, H.R. 2004. Knowledge spillovers and economic growth: An analysis using data of Dutch regions in the period 1987-1995. Regional Studies 38 (4): 393-407.

Verheul, I., Wennekers, A.R.M., Audretsch, D.B., and Thurik, A.R. 2002. An eclectic theory of entrepreneurship. In D.B. Audretsch, A.R. Thurik, I. Verheul and A.R.M. Wennekers (eds.), Entrepreneurship: Determinants and Policy in a European-US Comparison. Boston/ Dordrecht: Kluwer Academic Publishers, 11-81.

Wang, J.-Y., and Blomström, M. 1992. Foreign investment and technology transfer: A simple model. European Economic Review 36: 137-155.

Zahra, S. A., Duane Ireland, R. and Hitt, M.A. 2000. International expansion by new venture firms: international diversity, mode of market entry, technological learning, and performance, Academy of Management Journal, 43 (5): 925-950.

Zahra, S.A., Neubaum, D.O. and Huse, M. 1997. The effect of the environment on export performance among telecommunications new ventures, Entrepreneurship Theory and Practice, 22 (1): 25-46. 
Table 1: Correlation matrix $(\mathbf{N}=\mathbf{8 0})$

\begin{tabular}{|c|c|c|c|c|c|c|c|c|c|c|c|c|c|c|c|c|}
\hline & 1 & 2 & 3 & 4 & 5 & 6 & 7 & 8 & 9 & 10 & 11 & 12 & 13 & 14 & 15 & 16 \\
\hline \multicolumn{17}{|l|}{$\begin{array}{l}\text { 1. Total level of entrepreneurial } \\
\text { activity (TEA) }\end{array}$} \\
\hline 2. Entrepreneurs' export orientation & $\begin{array}{l}-0.24^{\mathrm{a}} \\
(\mathrm{N}=75)\end{array}$ & & & & & & & & & & & & & & & \\
\hline $\begin{array}{l}\text { 3. Inward FDI flow } \\
\text { (year t-1) }\end{array}$ & -0.15 & $0.24 *$ & & & & & & & & & & & & & & \\
\hline $\begin{array}{l}\text { 4. Outward FDI flow } \\
\text { (year t-1) }\end{array}$ & $-0.31 * *$ & $0.40^{* *}$ & $0.49 * *$ & & & & & & & & & & & & & \\
\hline $\begin{array}{l}\text { 5. Export of goods and services } \\
\text { (year t-1) }\end{array}$ & $-0.24 *$ & $0.56^{* *}$ & $0.58 * *$ & $0.43^{* *}$ & & & & & & & & & & & & \\
\hline $\begin{array}{l}\text { 6. Import of goods and services } \\
\text { (year t-1) }\end{array}$ & $-0.28 *$ & $0.57 * *$ & $0.55^{* *}$ & $0.42 * *$ & $0.98 * *$ & & & & & & & & & & & \\
\hline $\begin{array}{l}\text { 7. Employment share in } \\
\text { manufacturing }\end{array}$ & $-0.30 * *$ & 0.025 & -0.10 & -0.20 & -0.10 & -0.10 & & & & & & & & & & \\
\hline 8. Employment share in services & $-0.31 * *$ & $0.45^{* *}$ & 0.21 & $0.44^{* *}$ & $0.25^{*}$ & $0.24 *$ & $-0.29 * *$ & & & & & & & & & \\
\hline 9. Poor country dummy & $0.52 * *$ & $-0.42 * *$ & -0.11 & $-0.47 * *$ & $-0.24 *$ & $-0.26 *$ & -0.070 & $-0.56^{* *}$ & & & & & & & & \\
\hline 10. Economic growth & 0.056 & -0.0088 & 0.025 & -0.18 & 0.16 & 0.15 & -0.054 & $-0.34^{* *}$ & 0.18 & & & & & & & \\
\hline 11. Company-university cooperation & $-0.22 *$ & $0.33 * *$ & $0.26 *$ & $0.40^{* *}$ & 0.15 & 0.15 & $-0.25 *$ & $0.57 * *$ & $-0.53 * *$ & -0.13 & & & & & & \\
\hline 12. Ease of access to loans & $-0.37 * *$ & $0.40^{* *}$ & 0.20 & $0.53^{* *}$ & 0.20 & 0.18 & $-0.25^{*}$ & $0.65 * *$ & $-0.71 * *$ & $-0.25^{*}$ & $0.77 * *$ & & & & & \\
\hline 13. Tertiary education & $-0.22 *$ & $0.22 *$ & -0.071 & $0.25 *$ & -0.11 & -0.13 & 0.044 & $0.55^{* *}$ & $-0.70 * *$ & -0.17 & $0.57 * *$ & $0.58 * *$ & & & & \\
\hline 14. Log of GDP & -0.21 & $-0.45^{* *}$ & -0.18 & -.001 & $-0.33^{* *}$ & $-0.31^{* *}$ & -0.055 & -0.049 & -0.089 & -0.044 & -0.0065 & 0.048 & 0.18 & & & \\
\hline 15. Inflation rate & $0.51^{* *}$ & $-0.29 * *$ & -0.079 & $-0.24 *$ & $-0.23^{*}$ & $-0.29 * *$ & 0.13 & -0.13 & $0.48 * *$ & $-0.40 * *$ & $-0.32 * *$ & $-0.45^{* *}$ & -0.21 & $-0.22 *$ & & \\
\hline 16. Change in exchange rate & $-0.37 * *$ & 0.22 & 0.084 & $0.25^{*}$ & 0.11 & 0.12 & 0.010 & 0.14 & $-0.48 * *$ & $0.31^{* *}$ & $0.24 *$ & $0.41^{* *}$ & $0.28^{*}$ & 0.0078 & $-0.63 * *$ & \\
\hline Mean & 8.38 & 15.69 & 16.26 & 10.90 & 39.52 & 36.47 & 25.71 & 63.92 & 0.32 & 2.76 & 4.32 & 3.76 & 42.03 & 12.77 & 3.77 & 5.13 \\
\hline Standard deviation & 5.03 & 9.19 & 16.05 & 13.82 & 28.45 & 26.72 & 6.77 & 12.75 & 0.47 & 3.13 & 1.39 & 0.95 & 20.04 & 1.47 & 5.25 & 12.88 \\
\hline
\end{tabular}

$* p<.05 ; * * \mathrm{p}<.01$

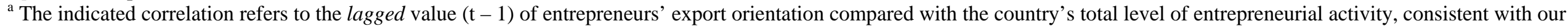
analysis in Table 4. 
Table 2: Estimation of the export orientation of a country's entrepreneurs $(\mathrm{N}=$ 80), short-term effects

\begin{tabular}{|c|c|c|c|c|c|c|c|}
\hline & Model 1 & Model 2 & Model 3 & Model 4 & Model 5 & Model 6 & Model 7 \\
\hline Constant & $34.9 * *$ & $35.1 * *$ & $36.7 * *$ & $28.1 *$ & $24.8 *$ & $28.1 *$ & $25.6 *$ \\
\hline $\begin{array}{l}\text { Employment share } \\
\text { manufacturing }\end{array}$ & $.26 *$ & $.25 *$ & $.26 *$ & $.22 *$ & $.23 *$ & $.23 *$ & $.24 *$ \\
\hline $\begin{array}{l}\text { Employment share } \\
\text { services }\end{array}$ & $.29 * *$ & $.29 *$ & $.26 * *$ & $.19 *$ & $.19 *$ & $.18 \#$ & $.18 \#$ \\
\hline $\begin{array}{l}\text { Poor country } \\
\text { dummy }\end{array}$ & -2.6 & -2.6 & -1.5 & .40 & 1.1 & 1.0 & 1.5 \\
\hline Economic growth & .22 & .21 & .18 & -.16 & -.12 & -.14 & -.092 \\
\hline $\begin{array}{l}\text { Company-university } \\
\text { cooperation }\end{array}$ & -.19 & -.22 & -.21 & -.24 & -.37 & -.30 & -.41 \\
\hline $\begin{array}{l}\text { Ease of access to } \\
\text { loans }\end{array}$ & .80 & .78 & .12 & .57 & 1.1 & .47 & .91 \\
\hline Tertiary education & -.031 & -.027 & -.0052 & .059 & .072 & .071 & .078 \\
\hline Log of GDP & $-3.3 * *$ & $-3.2 * *$ & $-3.3 * *$ & $-2.7 * *$ & $-2.7 * *$ & $-2.8 * *$ & $-2.8 * *$ \\
\hline Inflation rate & $-.74 * *$ & $-.74 * *$ & $-.77 * *$ & $-.69 * *$ & $-.62 * *$ & $-.68 * *$ & $-.62 *$ \\
\hline $\begin{array}{l}\text { Change in exchange } \\
\text { rate }\end{array}$ & -.16 & -.16 & -.16 & -.11 & -.10 & -.11 & -.11 \\
\hline $\begin{array}{l}\text { H1: Inward FDI } \\
\text { (year t-1) }\end{array}$ & & .0082 & & & & & \\
\hline $\begin{array}{l}\text { H2: Outward FDI } \\
\text { (year t-1) }\end{array}$ & & & $.11 *$ & & & .056 & .056 \\
\hline $\begin{array}{l}\text { H4: Export } \\
\text { (year t-1) }\end{array}$ & & & & $.10 * *$ & & & \\
\hline $\begin{array}{l}\text { H5: Import } \\
\text { (year t-1) }\end{array}$ & & & & & $.12 * *$ & & \\
\hline $\begin{array}{l}\text { H4-5: Total } \\
\text { international trade } \\
\text { (export + import) } \\
\text { (year t-1) }\end{array}$ & & & & & & $.050 * *$ & $.054 *$ \\
\hline $\begin{array}{l}\text { H6: Surplus in } \\
\text { international trade } \\
\text { (export - import) } \\
\text { (year t-1) }\end{array}$ & & & & & & & -.090 \\
\hline $\mathrm{R}^{2}$ & .558 & .558 & .576 & .610 & .615 & .617 & .619 \\
\hline Adjusted $\mathrm{R}^{2}$ & .471 & .463 & .485 & .526 & .532 & .527 & .522 \\
\hline
\end{tabular}

Notes: Dependent variable: Number of (early-stage) entrepreneurs with $26 \%$ or more of their customers located in foreign countries, as a \% of total (early-stage) entrepreneurs. Estimation method is OLS. Year dummies not reported.

** $p<0.01$; * $p<0.05 ; \# p<0.10$ (one-tailed tests). 
Table 3: Estimation of the export orientation of a country's entrepreneurs $(\mathbf{N}=$ 80), long-term effects

\begin{tabular}{|c|c|c|c|c|}
\hline & Model 8 & Model 9 & Model 10 & Model 11 \\
\hline Constant & $38.6 * *$ & $44.9 * *$ & $24.5 *$ & $35.9 * *$ \\
\hline Employment share manufacturing & $.24 *$ & $.23 *$ & $.22 *$ & $.22 *$ \\
\hline Employment share services & $.23 *$ & $.24 *$ & $.17 \#$ & $.17 \#$ \\
\hline Poor country dummy & -2.9 & -2.6 & 1.2 & -.22 \\
\hline Economic growth & .12 & .20 & -.15 & -.025 \\
\hline Company-university cooperation & -.23 & -.28 & -.37 & -.42 \\
\hline Ease of access to loans & -.015 & -1.1 & .89 & -.54 \\
\hline Tertiary education & .0068 & -.0034 & .072 & .065 \\
\hline Log of GDP & $-3.2 * *$ & $-3.4 * *$ & $-2.6 * *$ & $-2.9 * *$ \\
\hline Inflation rate & $-.73 * *$ & $-.65 * *$ & $-.64 * *$ & $-.60 * *$ \\
\hline Change in exchange rate & -.14 & -.11 & -.10 & -.087 \\
\hline H1: Inward FDI flow (year t-3) & $.063 *$ & & & .019 \\
\hline H2: Outward FDI flow (year t-6) & & $.21 * *$ & & $.15 * *$ \\
\hline $\begin{array}{l}\text { H4-5: Total international trade } \\
\text { (export + import) (year t-3) }\end{array}$ & & & $.069 * *$ & $.042 \#$ \\
\hline $\begin{array}{l}\text { H6: Surplus in international trade (export - } \\
\text { import) (year t-3) }\end{array}$ & & & & -.043 \\
\hline $\mathrm{R}^{2}$ & .583 & .631 & .631 & .658 \\
\hline Adjusted $\mathrm{R}^{2}$ & .493 & .551 & .551 & .564 \\
\hline
\end{tabular}

Notes: Dependent variable: Number of (early-stage) entrepreneurs stating that $26 \%$ or more of their customers are foreign, as \% of total (early-stage) entrepreneurs. Estimation method is OLS. Year dummies not reported. The results for the statistically optimal lags for inward FDI, outward FDI, and international trade include tested lags of up to seven years $(\mathrm{t}-7)$.

** $p<0.01$; * $p<0.05$; \# $p<0.10$ (one-tailed tests). 
Table 4: Estimation of a country's total level of entrepreneurial activity $(\mathbf{N}=75)$

\begin{tabular}{lccc}
\hline & Model 12 & Model 13 & Model 14 \\
\hline Constant & 14.5 & 14.2 & $18.5^{*}$ \\
Employment share manufacturing & $-.23 *$ & $-.22 *$ & $-.31 * *$ \\
Employment share services & -.14 & -.14 & $-.23 *$ \\
Poor country dummy & $4.0 *$ & $3.3^{*}$ & $5.6 * *$ \\
Economic growth & $.82 * *$ & $.83 * *$ & $.69 *$ \\
Company-university cooperation & -.31 & -.29 & -.54 \\
Ease of access to loans & .42 & .42 & .39 \\
Tertiary education & $.12 * *$ & $.12 * *$ & $.16 * *$ \\
Entrepreneurs' export orientation, & & -.015 & .20 \# \\
(year t-1) & & & IV \\
\hline Estimation method & OLS & OLS & Entrepreneurs' \\
Endogenous explanatory variable & & & export \\
& & & orientation \\
& & & (year t-1) \\
Instrument used & & & Log of GDP \\
& & & .346 \\
$\mathrm{R}^{2}$ & .491 & .492 & .243 \\
\hline Adjusted $\mathrm{R}^{2}$ & .421 & .413 & \\
\hline
\end{tabular}

Notes: Dependent variable: Number of (early-stage) entrepreneurs as \% of adult population (i.e., TEA index). Year dummies not reported.

${ }^{* *} p<0.01 ; * p<0.05$; $\# p<0.10$ (one-tailed tests). 


\section{Publications in the ERIM Report Series Research* in Management}

\section{ERIM Research Program: "Organizing for Performance"}

2007

Leadership Behaviour and Upward Feedback: Findings From a Longitudinal Intervention

Dirk van Dierendonck, Clare Haynes, Carol Borrill and Chris Stride

ERS-2007-003-ORG

http://hdl.handle.net/1765/8579

The Clean Development Mechanism: Institutionalizing New Power Relations

Bettina B.F. Wittneben

ERS-2007-004-ORG

http://hdl.handle.net/1765/8582

How Today's Consumers Perceive Tomorrow's Smart Products

Serge A. Rijsdijk and Erik Jan Hultink

ERS-2007-005-ORG

http://hdl.handle.net/1765/8984

Product Intelligence: Its Conceptualization, Measurement and Impact on Consumer Satisfaction

Serge A. Rijsdijk, Erik Jan Hultink and Adamantios Diamantopoulos

ERS-2007-006-ORG

http://hdl.handle.net/1765/8580

Testing the Strength of the Iron Cage: A Meta-Analysis of Neo-Institutional Theory

Pursey P.M.A.R. Heugens and Michel Lander

ERS-2007-007-ORG

http://hdl.handle.net/1765/8581

Export Orientation among New Ventures and Economic Growth

S. Jolanda A. Hessels and André van Stel

ERS-2007-008-ORG

http://hdl.handle.net/1765/8583

Allocation and Productivity of Time in New Ventures of Female and Male Entrepreneurs

Ingrid Verheul, Martin Carree and Roy Thurik

ERS-2007-009-ORG

http://hdl.handle.net/1765/8989

Cooperating if one's Goals are Collective-Based: Social Identification Effects in Social Dilemmas as a Function of Goal-Transformation David De Cremer, Daan van Knippenberg, Eric van Dijk and Esther van Leeuwen

ERS-2007-010-ORG

http://hdl.handle.net/1765/9041

Unfit to Learn? How Long View Organizations Adapt to Environmental Jolts

Pursey P. M. A. R. Heugens and Stelios C. Zyglidopoulos

ERS-2007-014-ORG

http://hdl.handle.net/1765/9404

Going, Going, Gone. Innovation and Exit in Manufacturing Firms

Elena Cefis and Orietta Marsili

ERS-2007-015-ORG

http://hdl.handle.net/1765/9732 
High in the Hierarchy: How Vertical Location and Judgments of Leaders' Power are Interrelated Steffen R. Giessner and Thomas W. Schubert

ERS-2007-021-ORG

http://hdl.handle.net/1765/9727

Contracts to Communities: a Processual Model of Organizational Virtue

Pursey P.M.A.R. Heugens, Muel Kaptein and J. van Oosterhout

ERS-2007-023-ORG

http://hdl.handle.net/1765/9728

Why Are Some Entrepreneurs More Innovative Than Others?

Philipp Koellinger

ERS-2007-024-ORG

http://hdl.handle.net/1765/9730

Stimulating Strategically Aligned Behaviour Among Employees

Cees B. M. van Riel, Guido Berens and Majorie Dijkstra

ERS-2007-029-ORG

http://hdl.handle.net/1765/10067

The Effectiveness of Business Codes: A Critical Examination of Existing Studies and the Development of an Integrated Research Model

Muel Kaptein and Mark Schwartz

ERS-2007-030-ORG

http://hdl.handle.net/1765/10150

Knowledge Spillovers and Entrepreneurs' Export Orientation

Dirk De Clercq, Jolanda Hessels and André van Stel

ERS-2007-038-ORG

* A complete overview of the ERIM Report Series Research in Management: https://ep.eur.nl/handle/1765/1

ERIM Research Programs:

LIS Business Processes, Logistics and Information Systems

ORG Organizing for Performance

MKT Marketing

F\&A Finance and Accounting

STR Strategy and Entrepreneurship 